\title{
FACTORS INFLUENCING TRAVELERS' ACCEPTANCE OF MOBILE MARKETING: COMPARATIVE ANALYSIS OF CHINA AND KAZAKHSTAN
}

\author{
Liang Wang \\ Harbin Institute of Technology, 92 West Xidazhi street Harbin, P R China
}

\section{Guoxin Li}

Harbin Institute of Technology, 92 West Xidazhi street Harbin, P R China

Bolatov Adilzhan

Harbin Institute of Technology, 92 West Xidazhi street Harbin, P R China

Portia Opoku Boadi

Harbin Institute of Technology, 92 West Xidazhi street Harbin, P R China

\begin{abstract}
The paper is aimed to examine factors affecting travelers' acceptance of mobile marketing in China and Kazakhstan. Based on technology acceptance theories we developed a conceptual model of antecedent factors and marketing-related mobile activity related to the acceptance of mobile marketing practice. The conceptual model is tested using data that collected through conducting survey among Chinese and Kazakhstan travelers.
\end{abstract}

Keywords: Mobile marketing acceptance, traveler, China, Kazakhstan

\section{JEL Code:H41}

\section{Introduction}

In the modern world technology is developing rapidly. In this regard the mobile technology is not exception. It is expected that this wireless computing device will become available soon. People have become mobile too. Rapid growth of such technologies impacted on developing new environment for interrelationship between travel agencies, travelers and other organization involved in tourism sphere. Since the online environment provides flexibility and accessibility, it is easy for travelers to browse and purchase travel products and services with only a few clicks of the mouse. Nowadays, it is necessary to explore new and innovative way to communicate with potential traveler. The time of 
traditional marketing, where marketers were pushing out messages toward consumers using only a one-way communication, is over. It is obliviously currently mobile marketing has huge impact on relationships between consumers and companies. It is important to develop the mobile marketing. However, in Kazakhstan research related to the tourism is considered is not serious, because of acceptance tourism as the science itself. Taking in consideration this fact, conducting research in tourism mobile marketing is critical issues. So, the purpose of this research is to understand traveler behavior faced to mobile marketing in tourism and more particular on online Kazakhstan travel market. It remains unclear to what extent consumers in markets such as China will accept and engage in mobile marketing efforts (Merisavo et al., 2007; Peng and Spencer, 2006).Numerous 24 International Journal of China Marketing vol. 2(2) 2012 academic studies have noted the challenges confronting mobile marketing communications acceptance, including feelings of intrusiveness as well as trust and privacy concerns among consumers (e.g. Grant and O'Donohoe, 2007). Several brands (e.g. ESPN, Sprite, and Adidas) have launched mobile marketing efforts only to see sparse successes amidst a number of disappointing results. The Chinese youth generation, while having readily embraced the internet and mobile phones, are more demanding than older generations, question the authenticity and accuracy of online and mobile information, and exhibit moderate to low levels of trust and satisfaction with new media (Meyer et al. 2009).

\section{Theoretical Model Acceptance of Mobile Marketing}

In computer-mediated communication, researchers acknowledge that the choice of information channel can be influenced by such factors as the amount of prior knowledge and experience(D. Kim, Park, \& Morrison, 2008; Varnali, 2010). (S. Kim \& Choi, n.d.) argued that consumers' experiences of trip or technology has an effect on new technology acceptance. Based on suggestion of related theories we proposed that trust, experience impact on attitudes towards mobile technology devices.

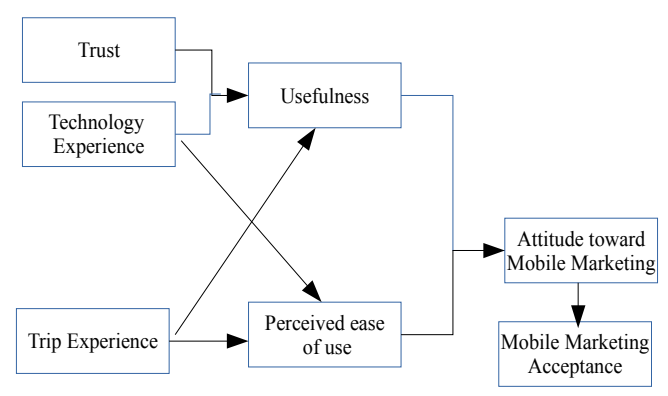

Figure 1: Research model

Within the context of tourism and hospitality, it can be reasonably assumed that previous technology and trip experiences influence travelers' attitudes and acceptance towards the adaptation of mobile technology devices.

Concerning studies within the TAM framework, prior research has empirically demonstrated a positive relationship between prior experience and acceptance of microcomputer technology, as well as being a predictor of technology usage. Specifically, actual behavioral experience is considered to be an important influence on beliefs such as perceived ease of use and perceived usefulness. Prior 
experiences in technology affect consumer beliefs and attitude towards related systems and technology. Thus, constructs, 'prior technology experience' is employed as antecedent construct that influence traveler' mobile acceptance in the research framework. Following this we suggest hypothesis:

H 1A: Technology experience is positively related with perceived usefulness.

H 1B: Technology experience is positively related with perceived ease of use.

Prior internet and computer usage experience would have a positive influence on adoption of new technology such as mobile technology in the research. Moreover, prior experience is consequently related to the two dimensions such as familiarity and expertise. In terms of acceptance of new technology within a certain context, therefore, people who are familiar with a product or service may feellittleneed for new information sources and consequently more likely to use new technology channel for the sake of convenience. In that sense, it is intuitivelyassumed that tripexperience also isrelated to channel acceptance withinth econtext of travel. Assuming noted above we suggested following hypothesis:

H 1C. Technology experience is positively related with trust.

H 2A. Trip experience is positively related with perceived usefulness.

H 2B. Trip experience is positively related with perceived ease of use.

The main aim of the nex thypotheses to investigate further of the effect of personalization of mobile marketing on consumer attitude towards mobile marketing. In order to understand the effect of this variable on consumer attitude. Here we suppose that perceived usefulness of mobile marketing predicted attitude towards mobile marketing, as well as perceived ease-of-use of mobile marketing predict attitude towards mobile marketing. Following thiswesuggested hypotheses 3,4 and 5:

H3. Perceived usefulness is positively related with attitudes towards using mobile devices for travel.

H4. Perceived ease of use is positively related with attitudes towards using mobile devices for travel.

H5. Trust is positively related with attitudes towards using mobile devices for travel

In this esearch, attitude is hypothesized to the influences of the acceptance of using mobile marketing services, and is defined as the degree to which an individual's attitude is favorably or unfavorably disposed towards using mobile services. Accordingly, we hypothesized that: H6. The attitude is positively related with the acceptance to use mobile devices for travel.

In suggested model, such variables as traveler's resident area (urban or rural: residents of urban area more intend to use m-marketing), age (it is believed that youth generation more intend to use $\mathrm{m}$ marketing than elder. Elder generation rely on face to face meeting with travel manager), income 
level (population with high income rely on travel managers than using m-marketing), travel purpose, job occupation would be considered. Therefore, the questionnaire consisted of two parts. In the first part, there are questions to determine demographic and categorical characteristics of participants.

\section{METHODOLOGY}

\subsection{Sample and data Sources}

In the research, the date is collected through survey forms. The survey form is prepared to determine the attitudes of Kazakhstan and China population. The study used an online survey to collect data. The survey was composed of 26 questions focusing largely on travelers' responses on: trip and technology experiences; general attitudes towards the use of m-marketing tools; and demographic information.

The items for the four constructs based on a 6-point Likert scale ( 1 for 'strongly disagree' to 6 for 'strongly agree').

The survey was conducted from the middle of February to the end of March.

In total sample size is 311: 150 respondents by China, 161 respondents by Kazakhstan.

The data analysis followed a several step procedure. First, Reliability analysis was conducted to check the model. Secondly, Frequency analysis provided a demographic profile of respondents. Characteristics of mobile usage were defined such as the type of mobile devices, locations and barriers to use were also analyzed. Thirdly, Confirmatory Factor Analysis was performed to analyze the underlying factor structure of the proposed constructs and to examine convergent and discriminant validity. Fourthly, SEM was used to explain the relationships within the proposed model.

The data is interpreted via IBM SPSS Statistics-23 and SmartPlus (v.3.2.6.) software environment for statistical computing and graphics.

\subsection{Reliability analysis}

The reliability analysis aims to measure whether the items are measuring the intended variables reliably or not. Cronbach's alpha is the most common measure of internal reliability (table 1). 
Table 1: Reliability analysis of factors

\begin{tabular}{ccc}
\hline Variable & $\begin{array}{c}\text { Cronbach } \\
\text { Alpha } \\
\text { China }\end{array}$ & $\begin{array}{c}\text { Cronbach } \\
\text { Alpha } \\
\text { Kazakhstan }\end{array}$ \\
\hline Perceived usefulness & 0.818 & 0.778 \\
\hline Technology Experience & 0.103 & 0.267 \\
\hline Trip Experience & 0,65 & 0,467 \\
\hline Perceived ease of use & 0.834 & 0.824 \\
\hline $\begin{array}{c}\text { Attitudes to mobile } \\
\text { technology }\end{array}$ & 0,826 & 0.778 \\
\hline Trust & 0.740 & 0.634 \\
\hline Acceptance & 0,675 & 0,283 \\
\hline
\end{tabular}

Cronbach's Alpha with a value greater than 0.70 indicates that the factor items are consistent in building the scales for the factors is consistent in them. On the other hand the factor 'Technology Experience' is found to have the Cronbach Alpha values of 0.103 and 0.267 for China and Kazakhstan respectively; indicating a lower reliability. Acceptance and trip experience also indicated lower reliability.

\subsection{Confirmatory factor analysis (CFA)}

To test whether measures of a construct are consistent with a researcher's understanding of the nature of that construct CFA was conducted.

A confirmatory factor analysis was conducted in SmartPLS software environment for statistical. Variables from the pilot test, were identified in the CFA: Usefulness, Technology experience (TechE), Trip Experience (TripE) Perceived Ease of Use (PEU), Attitude, Trust and Acceptance.

Results for China indicated the model had a good fit to the data, $\chi 2=756.185, \mathrm{p}<.0001, \mathrm{CFI}=.934$, $\mathrm{TLI}=.926, \mathrm{RMSEA}=.06(90 \%), \mathrm{SRMR}=.13$ for China and $\chi 2=742.4, \mathrm{p}<.0001, \mathrm{SRMR}=.08$ for Kazakhstan. All factor loadings were significant, which supported the convergent validity of the model. Unstandardized and standardized coefficient estimates are provided in Table 2 and 3. demonstrate the results of the CFA for China and Kazakhstan respectively.

Table 2: Fit Summary (for China)

\begin{tabular}{ccc}
\hline & Saturated Model & $\begin{array}{c}\text { Estimated } \\
\text { Model }\end{array}$ \\
\hline SRMR & 0.130 & 0.150 \\
\hline Chi-Square & 756.185 & 762.279 \\
\hline
\end{tabular}

Table 3: Fit Summary (for Kazakhstan)

\begin{tabular}{ccc}
\hline & Saturated Model & Estimated Model \\
\hline SRMR & 0.089 & 0.109 \\
\hline Chi-Square & 742.484 & 764.855 \\
\hline
\end{tabular}




\subsection{Structural equation model analysis}

The results of Structural equitation model for China (figure 2) indicated that the direct relationships between technology experience and perceived usefulness $(\beta=0.319)$ and perceived ease of use $(\beta=0.308)$ were positive at the $p=0.01$ level. Thus, hypothesises $\mathrm{H} 1 \mathrm{~A}$ and $\mathrm{H} 1 \mathrm{~B}$ are supported. Trip experience was positively related to perceived usefulness $(\beta=0.02)$ and negatively with perceived ease of use ( $\beta=-0.082)$. Following this results, we can maintain that hypothesis H2A is supported and hypothesis $\mathrm{H} 2 \mathrm{~B}$ is rejected. This indicated that trip experience had a greater influence on perceived usefulness than perceived ease of use. Both perceived usefulness $(\beta=0.247)$ and perceived ease of use $(\beta=0.553)$ were positively related to users' attitudes towards using mobile technology for travel (H4 and H5). That is, perceived ease of use more significantly influenced attitudes towards using mobile devices than perceived usefulness. Finally, the respondents' attitudes towards using mobile devices for travel were highly related to intentions to use mobile devices $(\beta=0.534$, H6). Figure $3-2$ demonstrates the results of the SEM from the full study.

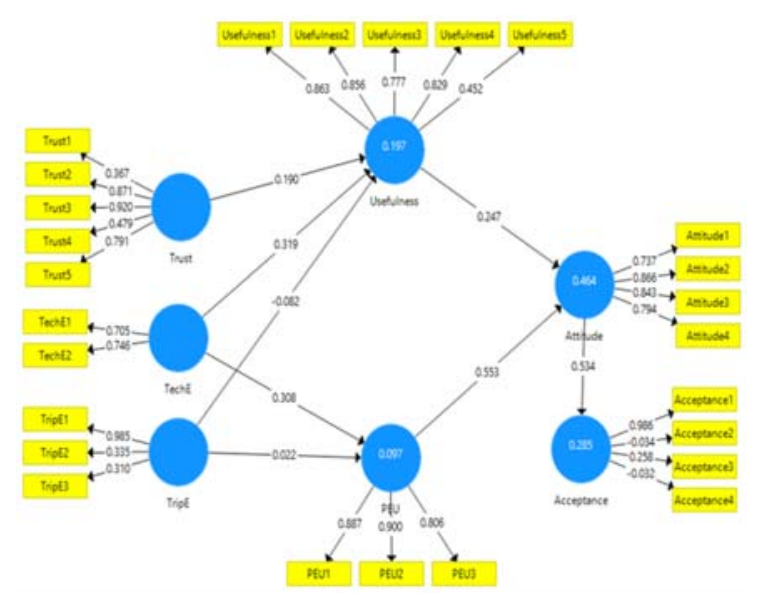

Figure 2: Structural equation modeling analysis of hypothesized model of traveler acceptance of mobile marketing in China

The indirect path coefficients (Table 3-13) showed that as traveler's technology experience increased, they were more likely to have positive attitudes towards using mobile devices $(\beta=0.249)$. Similarly, the relationship between trust and attitude toward mobile marketing is also positive $(\beta=$ 0.047). The links between travelers' prior trip experience and attitude toward mobile marketing ( $(==$ 0.08) was negative. This indicated that frequent travelers were more likely to have positive attitudes towards using mobile devices during trips and consequently more likely to have stronger acceptance of mobile devices.

Perceived ease of use had more influence on travelers' intentions to use mobile devices than perceived usefulness. This implied that the needs for using mobile devices were more related to the functional aspects of mobile devices (i.e. convenience, effectiveness and productivity) than hedonic aspects such as interaction with the devices and ease of use. 
Table 4: Direct and indirect path coefficients of China model

\begin{tabular}{ccc}
\hline Hypotheses path way & \multicolumn{2}{c}{ Standartised estimates } \\
\cline { 2 - 3 } & Direct & Indirect \\
\hline $\begin{array}{c}\text { Tech experience } \rightarrow \text { Perceived } \\
\text { ease of use }\end{array}$ & 0.308 & - \\
\hline $\begin{array}{c}\text { Tech experience } \rightarrow \text { Usefulness } \\
\text { MM }\end{array}$ & 0.319 & - \\
\hline $\begin{array}{c}\text { Tech experience } \rightarrow \text { Attitude to } \\
\text { ease of use }\end{array}$ & - & 0.249 \\
\hline $\begin{array}{c}\text { Trip experience } \rightarrow \text { Perceived } \\
\text { MM }\end{array}$ & 0.022 & - \\
\hline Trip experience $\rightarrow$ Usefulness & -0.082 & - \\
\hline $\begin{array}{c}\text { Trip experience } \rightarrow \text { Attitude to } \\
\text { MM }\end{array}$ & - & -0.008 \\
\hline $\begin{array}{c}\text { Perceived ease of use } \rightarrow \\
\text { Attitude to MM }\end{array}$ & 0.553 & - \\
\hline $\begin{array}{c}\text { Usefulness } \rightarrow \text { Attitude to MM } \\
\text { Trust } \rightarrow \text { Usefulness }\end{array}$ & 0.247 & - \\
\hline Trust $\rightarrow$ Acceptance & 0.190 & - \\
\hline Attitude $\rightarrow$ Acceptance & - & 0.025 \\
\hline
\end{tabular}

Table 5:Variablecorrelation (for China)

\begin{tabular}{cccccccc}
\hline & $\begin{array}{c}\text { Accep- } \\
\text { tance }\end{array}$ & $\begin{array}{c}\text { Attitu- } \\
\text { de }\end{array}$ & PEU & TechE & TripE & Trust & $\begin{array}{c}\text { Useful- } \\
\text { ness }\end{array}$ \\
\hline $\begin{array}{c}\text { Accep- } \\
\text { tance }\end{array}$ & 1.000 & & & & & & \\
\hline $\begin{array}{c}\text { Attitu- } \\
\text { de }\end{array}$ & 0.534 & 1.000 & & & & & \\
\hline PEU & 0.871 & 0.641 & 1.000 & & & & \\
\hline TechE & 0.219 & 0.359 & 0.311 & 1.000 & & & \\
\hline TripE & -0.032 & -0.066 & 0.059 & 0.120 & 1.000 & & \\
\hline Trust & 0.151 & 0.400 & 0.303 & 0.511 & 0.094 & 1.000 & \\
\hline Useful- & 0.405 & 0.443 & 0.355 & 0.406 & -0.025 & 0.345 & 1.000 \\
ness & & & & & & &
\end{tabular}

From the correlations table in table 5 can be concluded that all independent variables have a relationship with the dependent variable, however both innovativeness and existing knowledge show a relationship below 0.3, of 0.075 and 0.027 respectively. Trip Experience and Usefulness are the variables that shows a negative relationship of -0.032 (trip experience with acceptance, trip experience with attitude -0.066 , usefulness with trip experience -0.025). Furthermore, Tabachnick \& Fidell (2001) say that one should think carefully before including two variables with a bivariate correlation of above 0.7 or more in the same analysis. In this analysis all variables meet this expectation except for Perceived ease of use and Acceptance which show a bivariate correlation of 0.871 .

The results of Structural equation modelling analysis of Kazakhstan indicated that the direct relationships between technology experience and perceived usefulness $(\beta=0.325)$ and perceived ease 
of use $(\beta=0.252)$ were positive at the $p=0.01$ level. Thus hypotheses H $1 \mathrm{~A}$ and H $1 \mathrm{~B}$ are supported. However, trip experience was negatively related to perceived usefulness $(\beta=-0.079)$ as well as with perceived ease of use $(\beta=-0.011)$. Following this results we can maintain that hypothesizes $\mathrm{H} 2 \mathrm{~A}$ and H2B are rejected. Both perceived usefulness $(\beta=0.337)$ and perceived ease of use $(\beta=0.457)$ were positively related to users' attitudes towards using mobile technology for travel ( $\mathrm{H} 4$ and H5). That is, perceived ease of use more significantly influenced attitudes towards using mobile devices than perceived usefulness. Finally, the respondents' attitudes towards using mobile devices for travel were related to acceptance to use mobile devices $(\beta=0.143, \mathrm{H} 6)$.

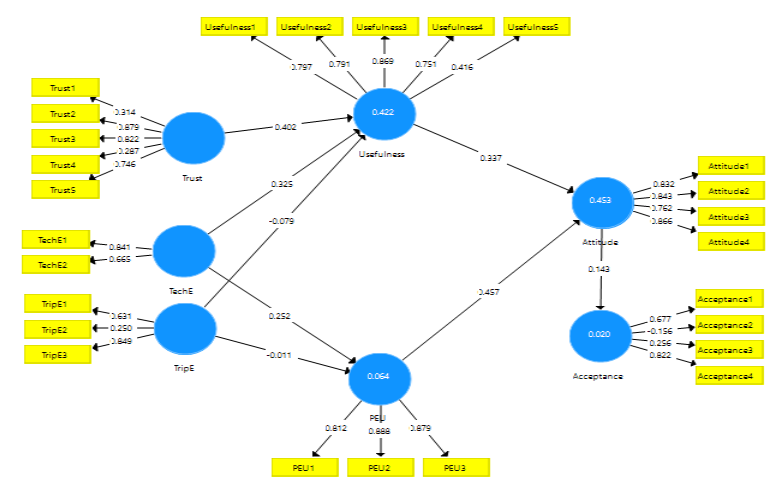

Figure 3: Structural equation modeling analysis of hypothesized model of traveler acceptance of mobile marketing in Kazakhstan

The indirect path coefficients (Table 3-18) showed that as traveler's technology experience increased, they were more likely to have positive attitudes towards using mobile devices $(B=0.224)$. Similarly, the relationship between trust and attitude toward mobile marketing is also positive $(\beta=0.135)$. The links between travelers' prior trip experience and attitude toward mobile marketing $(\beta=-0.008)$ was negative.

Table 6: Direct and indirect path coefficients

\begin{tabular}{ccc}
\hline \multirow{2}{*}{ Hypotheses path way } & \multicolumn{2}{c}{ Standardized estimates } \\
\cline { 2 - 3 } & Direct & Indirect \\
\hline $\begin{array}{c}\text { Tech experience } \rightarrow \text { Perceived } \\
\text { ease of use }\end{array}$ & 0.252 & \\
\hline $\begin{array}{c}\text { Tech experience } \rightarrow \\
\text { Usefulness }\end{array}$ & 0.325 & \\
\hline $\begin{array}{c}\text { Tech experience } \rightarrow \text { Attitude to } \\
\text { MM }\end{array}$ & & \\
\hline $\begin{array}{c}\text { Trip experience } \rightarrow \text { Perceived } \\
\text { ease of use }\end{array}$ & -0.010 & -0.031 \\
\hline Trip experience $\rightarrow$ Usefulness & -0.079 & -0.008 \\
\hline $\begin{array}{c}\text { Trip experience } \rightarrow \text { Attitude to } \\
\text { MM }\end{array}$ & \\
\hline $\begin{array}{c}\text { Perceived ease of use } \rightarrow \\
\text { Attitude to MM }\end{array}$ & 0.457 & \\
\hline $\begin{array}{c}\text { Usefulness } \rightarrow \text { Attitude to MM } \\
\text { Trust } \rightarrow \text { Usefulness }\end{array}$ & 0.337 & \\
\hline $\begin{array}{c}\text { Trust } \rightarrow \text { Attitude } \\
\text { Attitude } \rightarrow \text { Acceptance }\end{array}$ & 0.402 & 0.135 \\
\hline
\end{tabular}


Table 7: Variable Correlations

\begin{tabular}{cccccccc}
\hline & $\begin{array}{c}\text { Accep- } \\
\text { tance }\end{array}$ & Attitude & PEU & TechE & TripE & Trust & $\begin{array}{c}\text { Usefu- } \\
\text { lness }\end{array}$ \\
\hline Acceptance & 1.000 & & & & & & \\
\hline Attitude & 0.143 & 1.000 & & & & \\
\hline PEU & 0.146 & 0.600 & 1.000 & & & \\
\hline TechE & 0.044 & 0.274 & 0.253 & 1.000 & & \\
\hline TripE & -0.198 & -0.014 & -0.042 & -0.123 & 1.000 & & \\
\hline Trust & 0.091 & 0.497 & 0.379 & 0.540 & -0.008 & 1.000 & \\
\hline Usefulness & 0.138 & 0.530 & 0.423 & 0.552 & -0.122 & 0.578 & 1.000 \\
\hline
\end{tabular}

From the correlations table in table 3-19 can be concluded that all independent variables have a relationship with the dependent variable. However, Trip Experience and Usefulness are the variables that shows a negative relationship. Trip experience had negative relationship with almost all of variables. The other variables meet this expectation.

The study uncovered important insights regarding youth consumers and their acceptance of mobile marketing. Our findings illustrated a common influence across both tourism markets. However, our findings also pointed to several cross-market differences related to respondents' participation in mobile marketing activity.

\section{Summary}

A cross-market comparison of average scores for our key variables highlighted several differences among the China and Kazakhstan (see Table 1). China respondents indicated greater perceived usefulness and personal attachment to their mobile devices, as well as greater attitudes toward mobile marketing in general, than did respondents from China and Kazakhstan. Kazakhstan respondents indicated significantly higher risk avoidance as compared to respondents from the China. Selfreported mobile marketing activity (e.g., purchasing and downloading items via one's mobile phone) was highest among Chinese respondents.

One of the key and significant factors in mobile marketing is consumer satisfaction, in our case mobile marketing for traveling purpose. The traveler behavior and attitude of the two samples are different.

According to this model a traveler's attitude toward mobile marketing is influenced by its technology experience perceived ease of use of mobile marketing tools, the trip experience and showed low 
significant in both of countries (tTripE -> Usefulness $=1,137$ for China and tTripE $->$ Usefulness $=$ 0,854 for Kazakhstan).

Table 8: Comparison of variables means across two countries

\begin{tabular}{ccccccc}
\hline \multirow{2}{*}{ Variables } & \multicolumn{2}{c}{ Means } & \multicolumn{2}{c}{$\begin{array}{c}\text { Standard } \\
\text { Deviation }\end{array}$} & \multicolumn{2}{c}{$\begin{array}{c}\text { T-test of Mean } \\
\text { Differences }\end{array}$} \\
\cline { 2 - 7 } & $\mathrm{C}$ & $\mathrm{K}$ & $\mathrm{C}$ & $\mathrm{K}$ & $\mathrm{C}$ & $\mathrm{K}$ \\
\hline $\begin{array}{c}\text { Attitude -> } \\
\text { Acceptance }\end{array}$ & 0,544 & 0,159 & 0,068 & 0,149 & 7,889 & 0,955 \\
\hline $\begin{array}{c}\text { PEU -> } \\
\text { Attitude }\end{array}$ & 0,621 & 0,467 & 0,079 & 0,064 & 7,595 & 7,113 \\
\hline TechE -> PEU & 0,334 & 0,248 & 0,105 & 0,082 & 3,107 & 3,090 \\
\hline $\begin{array}{c}\text { TechE -> } \\
\text { Usefulness }\end{array}$ & 0,233 & 0,320 & 0,157 & 0,092 & 1,752 & 3,549 \\
\hline TripE -> PEU & 0,009 & $-0,022$ & 0,087 & 0,078 & 0,072 & 0,138 \\
\hline $\begin{array}{c}\text { TripE -> } \\
\text { Usefulness }\end{array}$ & 0,120 & $-0,060$ & 0,093 & 0,093 & 1,137 & 0,854 \\
\hline $\begin{array}{c}\text { Trust -> } \\
\text { Usefulness }\end{array}$ & 0,286 & 0,416 & 0,099 & 0,080 & 2,138 & 4,997 \\
\hline \multicolumn{7}{c}{$\mathrm{C}=$ China; $\mathrm{K}=$ Kazakhstan } \\
\end{tabular}

The results in Table provide support for the H1, H3, H4, H5 and H6 hypotheses for China and for Kazakhstan. Hypothesis 1 posited a positive relationship between Travelers' technology experiences and attitudes towards mobile marketing.

Consistent with $\mathrm{H} 1$, the result in Table, indicates that in China there is a significant $(\mathrm{t}=3,107)$ positive $(\beta=0,334)$ relationship between Technology experience and perceived usefulness.

There is a significant and positive relationship between technology experience, perceived usefulness, perceived ease of use with attitudes of travelers toward mobile marketing in both China and Kazakhstan. There is also a significant and positive relationship is found among trust and usefulness of mobile marketing. Moreover, there is a significant and negative relationship between Trip experience and perceived ease of use $(t=0,138, \beta=-0,022)$, as well as usefulness $(t=0,854, \beta=-0,060)$ in Kazakhstan. In there is a significant and negative relationship between Trip experience and perceived usefulness $(t=1,137, \beta=-0,120)$.

\section{DISCUSSION AND CONCLUSIONS}

Mobile technology offers unprecedented opportunities and challenges for organizations in successfully capturing the attention of consumers and communicating marketing messages to targeted audiences. Tourism and hospitality organizations are now trying to develop a better understanding of mobile service needs and preferences. This study will contribute to that process by providing a comprehensive user acceptance model of mobile technology. The results should make tourism and hospitality marketers aware of the factors they should consider in attracting customers by using mobile technology. The study also contributes to theory building by considering mobile 
technology acceptance in the tourism and hospitality context. Moreover, it successfully developed and tested an extensive model of the traveler mobile technology adaptation by including the external factors of technology and trip experience.

The results supported all the hypotheses regarding how attitudinal factors were related to travelers' intentions to use mobile devices. Travelers' technology and trip experience appear to be influential factors in mobile technology adaptation. The findings suggest that frequent travelers have more positive attitudes in using mobile devices and have a higher intention to use them on trips in China than in Kazakhstan. That is, frequent travelers have stronger mobile usage needs for trips. This implies that tourism and hospitality marketers should consider using mobile services as one of the key elements in attracting frequent travelers. Providing mobile and wireless services will make properties and facilities more relevant, meaningful, effective and engaging Perceived usefulness and perceived ease of use were important factors in mobile technology model tested. Perceived usefulness had a stronger impact on predicting users' attitudes and intentions to use mobile devices during trips. Therefore, travelers' needs for using mobile devices more closely related to perceived usefulness (i.e. convenience, effectiveness and productivity) than perceived ease of use (e.g. interaction with the devices and ease of use). The need for effective functionalities and a wider scope of mobile services in tourism and hospitality locations should be important issues of concern for industry marketers, especially given frequent travelers' higher preferences to use mobile devices. The promotion and presentation of mobile provision services to potential customers should reflect the attitudinal factors in the model (i.e. perceived usefulness). Travelers will be more attracted to hotel and restaurant properties that provide free mobile and wireless services.

\section{REFERENCES}

Kim, D., Park, J., \& Morrison, A. M. (2008). A model of traveller acceptance of mobile technology. International Journal of Tourism Research, 10(5), pp. 393-407.

Kim, S., \& Choi, H. (n.d.). Design of Mobile Tourism Contents service in Northern Gyeongbuk Province, Korea. The KCS Thesis Journal, 7(2007), pp. 116-122.

Varnali, K. (2010). International Journal of Information Management Mobile marketing research : The-state-of-the-art. International Journal of Information Management, 30, pp. 144-151. https://doi.org/10.1016/j.ijinfomgt.2009.08.009

Grant, I.and O’Donohoe, S.(2007). Why young consumers are not open to mobile marketing communications. International Journal of Advertising, Vol. 26 No. 2, pp. 223-46.

Merisavo,M.,Kajalo,S.,Karjaluoto,H.,Virtanen,V.,Salmenkivi,S.,Raulas,M.and Leppaniemi, M.(2007). An empirical studyof the drivers of consumer acceptanceof mobile advertising. Journal of Interactive Advertising,Vol.7No. 2, pp. 95-109.

Gong, W. and Li, Z.G. (2008) .Mobile youth in China: a cultural perspective and marketing implications. International Journal of Electronic Business, Vol. 6 No. 3, pp. 261-81. 
Sultan, F., Rohm, A.J. and Gao, T. ((2009). FactorsInfluencing consumer acceptance of mobile marketing: a two-country study of youth markets. Journal of InteractiveMarketing, Vol. 23 No. 4, pp. 308-20.

Bernier, P. (2014). Mobile Marketing. Customer, 32(7), pp.26-28.

Meyer, M.,Michael, D.C. and Nettesheim, C. (2009). Reaching China's digital consumers. China Business Review, Vol. 36 No. 1, 24-7.

M. Kim and H. Qu, "Travelers' behavioral intention toward hotel self-service kiosks usage," Int. J. Contemp. Hosp. Manag., vol. 26, no. 2, pp. 225-245, 2014. 